\title{
Fictional and Aesthetic Objects: Meinong's Point of View
}

\author{
Venanzio Raspa
}

In contemporary philosophy there are a great many texts on aesthetics and the ontology of narrative discourse, that discuss Meinong's theses, agreeing or disagreeing. But Meinong never wrote a single book or article on aesthetics or the ontology of art works, nor did he provide a structured system to deal with fictional aesthetic objects. What he wrote on these matters is to be found in texts dealing with the wide horizon represented by object theory. To assess whether object theory provides the right tools for the treatment of fictional aesthetic objects and hence deserves to be looked at in greater depth and developed further, I have thought fit to consider certain critical points from a general point of view, passing over specific analyses.

Meinong does not use the term 'fictional,' indeed he only speaks of 'aesthetic objects'; having brought together the two terms to delimit my discourse, I will not deal with fictitious objects in their totality, but only with the subclass of fictional aesthetic objects. By 'fictional' I mean 'figuring in fiction,' i.e. in a story or narrative context - of course not all that is fictitious is necessarily given in a narrative context; whereas by 'aesthetic object' I mean an object with aesthetic properties - and again, not all that is fictitious (including the fictional) is also necessarily an aesthetic object. Meinong himself refers above all to literature, sometimes to music, seldom to the visual arts, when he speaks of aesthetic objects.

1. Meinong's discourse on fictional objects follows from certain fundamental theses of object theory. Such theses, put forward for the first time in 'The Theory of Objects [Über Gegenstandstheorie]' (1904), mainly come out of a process of theoretical elaboration which began years before, especially with 'On Objects of Higher Order and their Relationship to Internal Perception [Über Gegenstände höherer Ordnung und deren Verhältnis zur inneren Wahrnehmung]' (1899) and 
On Assumptions [Ueber Annahmen] (1902) ${ }^{1}$. Later they underwent further development, but were never abandoned. Here I take them as premises, and do no more than set them out, without going into detail ${ }^{2}$.

First of all, Meinong embraces Brentano's thesis of intentionality, according to which every mental phenomenon (representation, judgment, feeling or desire) is directed towards an object ${ }^{3}$ :

For no one doubts that we cannot have a representation, without having a representation of something, and likewise, that we cannot judge without judging something ${ }^{4}$.

This intentional character secures an autonomous and specific domain for the mental and allows it to be distinguished from the physical. To these two classes Meinong adds a third, that of ideal objects, which are neither physical nor mental. He comes to this, following Twardowski, by connecting the intentionality thesis with the distinction between the act, content and object of a representation 5 .

${ }^{1}$ Meinong's works, except the first edition of Ueber Annahmen (1902), are quoted from the Alexius Meinong Gesamtausgabe (1968-1978), abbreviated as GA. Translations are mine, unless indicated otherwise; references to English translations appear in brackets.

2 But cf. the already classic texts by Findlay $1963^{2}$ and Grossmann 1974; for more specific logical aspects, see Lambert 1983 and Jacquette 1996. A brief exposition of the main theses of object theory can be found in Raspa 2006.

${ }^{3}$ Cf. Brentano 18741/1924-192822: I, 124 ff., 136 ff.; II, 32.

${ }^{4}$ Meinong 1899: GA II, 381 (1978: 141). Cf. also Meinong 1904: GA II, 381 (1960: 76): 'That knowing is impossible without something being known, and more generally, that judgments and ideas or representations (Vorstellungen) are impossible without being judgments about and representations of something, is revealed to be self-evident;'; 1905: GA I, 582: 'one cannot be cheered up without being glad about something. Hence one cannot feel any joy, without apprehending such a 'something', an object' (see infra, fn. 8); 1921: GA VII, 15. 1974: 224. I translate 'Vorstellung' with 'representation', and not with 'idea' (like SchubertKalsi) or 'presentation' (like Levi, Terrell and Chisholm), because we find in Meinong both the terms 'Idee' and 'Präsentation'. On this question cf. Lindenfeld 1980: 17 , fn. 6 .

${ }^{5}$ Cf. e.g. Twardowski 1894: 3-4, 12, 18 (1977: 1-2, 10, 16); Meinong 1899: GA II, 381 ff. (1978: 141 ff.). 
An act is a psychical experience (Erlebnis) directed toward an object; content is that part of such an experience that varies or remains constant with the object, and in dependence upon it ${ }^{6}$; the object is, still following Twardowski ${ }^{7}$, the summum genus, in other words that something to which no other concept is superordinate ${ }^{8}$. This is fundamental because it means that anything that can be apprehended by a mental experience or expressed by language is an object; but furthermore that 'object' for Meinong is not binding as regards the being or essence of something.

Meinong can then distinguish between what exists and what - while either subsisting or being outside of being (außerseiend) - does not: existence is characterized by persistence in time, and is a predicate not possessed by all objects; so there are objects that, rather than existing, only subsist, having no spatio-temporal determination (such as the objects of mathematics $)^{9}$, as well as objects that neither exist nor subsist, and hence are outside of being (impossible objects). Being can hence be either existence or subsistence.

Such distinctions imply a criticism of the prejudice in favour of existence or being ${ }^{10}$, according to which 'we may speak of a so-being

${ }^{6}$ Cf. Meinong 1899: GA II, 384 (1978: 142-143); 1917: GA III, 339 ff., 347 f. (1972: 49 ff., 55 f.).

${ }^{7}$ Cf. Twardowski 1894: 37, 38, 40 (1977: 34, 35, 37).

8 Cf. Meinong 1921: GA VII, 14 (1974: 224). According to Meinong (1904: GA II, 483-484 (1960: 77)), there is an equivalence between 'object' and 'something'. This meaning of object is similar to that of object in general (Gegenstand überhaupt) found in the Critique of Pure Reason: the concept of an object in general - affirms Kant $\left(1781^{1}-1787^{2}\right.$ : A $290=$ B 346) at the end of the Transcendental Analytic - is the highest concept (beyond the dichotomy of possible and impossible), with which it remains undecided whether the object is something or nothing. ${ }^{9}$ Cf. Meinong 1902: $189=G A$ IV, 467; 1904: GA II, 519 (1960: 108); 1906: GA V, 377 fn. 2, 387-388; 1910: GA IV, 64, $74-75$ (1983: 52, 58-59); 1915: GA VI, 56-57, 61 ff.; 1918: GA V, 544; 1921: GA VII, 20-21 (1974: 228).

10 Actually Meinong speaks of a 'prejudice in favour of the real' (1904: GA II, 485, 505 (1960: 78, 96); 1906-1907: GA V, 235, 255), or 'of the knowledge of reality' (1904: $G A$ II, 488 (1960: 81)), in addition to a 'prejudice in favour of existence' (1904: $G A$ II, 489, 494 (1960: 82, 86); 1915: GA VI, 181, 201), or 'of being' (1904: GA II, 494 (1960: 86)). According to him 'existence', 'reality' and 
(Sosein) only if a being (Sein) is always presupposed'11, and only reality is worthy of theoretical treatment ${ }^{12}$. They conversely presuppose the postulation of an existence-free science (daseinsfreie Wissenschaft), that is 'an aprioristic science, independent from experience'13. The concept of Daseinsfreiheit finds expression in two fundamental principles: the principle of independence of so-being from being and the principle of the Außersein. According to the former

the so-being (Sosein) of an object is not affected by its non-being (Nichtsein). $[\ldots]$ this principle applies, not only to objects which do not exist in fact, but also to objects which could not exist because they are impossible ${ }^{14}$.

The other principle, of Außersein, often translated as 'principle of the indifference of pure object to being', affirms that

the object as such, [...] the pure object, stands 'beyond being and non-being.' [...] The object is by nature outside of being [or indifferent to being (außerseiend)], although at least one of its two objectives of being, the Object's being or non-being, in every case subsists ${ }^{15}$.

Later on I will explain what Meinong means by Außersein. Regarding the classification of objects, in addition to the above ontological one, Meinong also gives a gnoseological one: namely the classification of objects according to the psychical experiences that apprehend them, so that 'objecta' (Objekte) are the objects of representations, 'objectives' (Objektive) those of thoughts (judgments and assumptions), 'dignitatives' (Dignitative) those of feelings, and 'desideratives' (Desiderative) those of desires. We can concentrate on the first two classes of objects. The former, the objecta, can be objects of lower or of higher order, these last being characterized by an 'intrinsic non-independence'

'being' are not synonymous, but they are, in order, concepts with an increasing extension. This use of different expressions is not a symptom of linguistic inaccuracy or lack of conceptual clarity; rather, they are indicative of the various levels in which the prejudice operates (cf. Barbero \& Raspa (eds.) 2005: 7-8).

11 Meinong 1904: GA II, 489 (1960: 82).

12 Cf. Meinong 1904: GA II, 486 (1960: 79).

13 Meinong 1906-1907: GA V, 239, 256-257.

14 Meinong 1904: GA II, 489, 490 (1960: 82).

15 Meinong 1904: GA II, 493-494 (1960: 86); the translation has been slightly modified (V.R). 
(innere Unselbständigkeit) ${ }^{16}$, because they can only be thought in reference to other objects, on which they are built. They can be both ideal, like the relation of similarity between two things, and real, like the combination between a colour and an extension. What can exist is real $^{17}$, what can subsist ideal18. Objectives are also objects of higher order: as judgment needs representations as its essential basis, so the objective needs objecta; in fact an objective can also be the inferius of another objective, but at the end of the downward series we always find objecta, by the principle of obligatory infima ${ }^{19}$. Unlike objecta, which can exist or not, objectives can never exist as a piece of reality next to the objecta that occur in them, but they can only subsist, when they are true.

I have stated known Meinongian principles and definitions that I will use later on. I have done this for two reasons: because the discourse that I will develop is of a hypothetical kind, in the sense that, having assumed certain ontological theses, it investigates their consequences of an aesthetic nature; and because, since the non-acceptance of the presuppositions means that we can (not necessarily that we must) disagree on the results, proceeding in this way helps to make clear the points of divergence. My paper is structured in three parts, each of which moves from a polemic that involved Meinong; therefore, the theory is immediately subjected to a first verification. Each part intends to answer a question: (i) what kind of existence or of being is possessed by fictional aesthetic objects? (ii) what kind of objects are fictional aesthetic objects? (iii) what makes a fictional object an aesthetic one?

2. Let us begin with the first question: what kind of existence or of being is possessed by fictional aesthetic objects? To enter directly in medias res, we should consider the following passage:

\footnotetext{
16 Meinong 1899: GA II, 386 (1978: 144).

17 Cf. Meinong 1899: GA II, 394 (1978: 150).

18 Cf. Meinong 1899: GA II, 395 (1978: 150).

19 Cf. Meinong 1910: GA IV, 62-63 (1983: 50-51); 1917: GA III, 389-390 (1972: 94); 1921: GA VII, 17 (1974: 226).
} 
I know that Goethe's Mephistus is a mere poetic form, that there has never been a Mephistus, that therefore none of the words that Goethe makes him say have ever been uttered by him. Nevertheless, I can discuss how Mephistus replies to Faust or to the Lord in a certain passage. I can say that he 'effectively' responds in a certain way and not in another.

And it should be noted that with this I do not want to formulate a judgment either on my or on Goethe's imaginative activity, but I formulate it on the person of Mephistus. [...] for me or for my consciousness Mephistus' answer does not belong to the past, but to the immediate present. Contrarily, Goethe's imaginative activity is without doubt a past fact.

On the other hand, I do not speak at all of the historical Mephistus, but rather of Goethe's, or more precisely of the Mephistus of the story. But he has a peculiar form of existence. Without any doubt he was once called into existence by Goethe. But having been called into existence and having reached artistic representation in the words of literature, he has a type of reality; what he does and says is in a certain sense beyond any doubt a verifiable ' $f a c t$ ' 20 .

What type of reality does Mephistus have? An 'aesthetic reality' (ästhetische Wirklichkeit), is the answer of the author of this passage, where the adjective 'aesthetic' means that what is concerned is an invented reality, that does not have anything to do with the real world, but only with its being thought, therefore it can also be defined as an 'existence for me' (Dasein für mich) ${ }^{21}$. It is not Meinong who is talking, but one of his contemporaries, the philosopher Theodor Lipps, in an essay of 1905 'Weiteres zur 'Einfühlung' [Further considerations on 'Empathy']', in which Meinong is called to account on questions regarding judgement-feelings, aesthetic feelings and aesthetic pleasure. Meinong responds to Lipps the same year with an article published in the same review, the Archiv für die gesamte Psychologie, and entitled 'Judgement-feelings: what they are and what they are not [Über Urteilsgefühle: was sie sind und was sie nicht sind].' This was written shortly after the publication of the essay 'The Theory of Objects', and it not only presents an aesthetic application of object-

20 Lipps 1905: 487-488.

21 Cf. Lipps 1905: 489; 1906: 27. 
theoretical concepts which were presented in that essay, but it also anticipates many elements that will be developed more completely in Meinong's mature works. I will not follow the whole development of the polemic, which continued with another article published by Lipps the following year under a similar title, 'On 'Judgement-feelings' [Über 'Urteilsgefühle']'; I will instead confine myself to examining those aspects that help us to understand better Meinong's position on fictional aesthetic objects.

From the passage of Lipps the following theses emerge:

(L1) the Mephistus of Goethe's Faust never existed and, if he did not exist, he neither uttered the words that Goethe makes him say nor performed the actions that he makes him perform;

(L2) but it is a fact that we can discuss what Mephistus said and did, and when we do this, we refer to Mephistus, the one of the literary story, and not to our or Goethe's imaginative activity. How is this possible? And this brings us to a third thesis:

(L3) once he has been called into existence by Goethe, Mephistus possesses a type of reality that does not have anything to do with proper reality, a type of reality that Lipps names 'aesthetic', and that corresponds to being thought.

It is of little consequence that subsequently Lipps replaces the term 'aesthetic reality' with that of 'aesthetic objectivity' (ästhetische Objektivität) ${ }^{22}$; and we can also disregard his interchangeable use of the terms 'existence' and 'reality.' What is however significant is that Mephistus is according to Lipps an object provided with a specific kind of reality corresponding to being thought.

Now, Meinong shares theses (L1) and (L2) in accordance with his critique of the prejudice in favour of the real, but he disagrees with (L3). In his opinion, we can talk about an 'aesthetic reality' only in a metaphoric sense. Here is what he says:

Strictly speaking there is only one reality, that of the empirical world, and an 'aesthetic reality' that is outside of it is not reality at all ${ }^{23}$.

22 Cf. Lipps 1906: 28.

23 Meinong 1905: GA I, 599. 
The same can be said for the notion of a 'simple and indisputable existence of an object for me in general', because an existence for me, in my mind, exists only in the sense of an 'existing in a representation', that is in the sense of a pseudo-existence (as defined by Meinong in the essay 'On Objects of Higher Order'24). In such a case, what exists is the representational act including its content, but Mephistus cannot be understood as a psychical content, for the simple fact that he possesses some properties and accomplishes some actions that can as little be attributed to a representational content, as being cold and sweet can be attributed to the psychical representation of a ice-cream ${ }^{25}$. Despite the dissent, what remains from Lipps's lesson is that with reference to Mephistus, on one hand we are dealing with real psychical experiences, on the other hand with an unreal object. It is a fact that literary stories arouse in us not only thoughts, but also feelings and emotions, and that from this we derive aesthetic pleasure. But how can something unreal, that does not exist, generate real effects, that do nevertheless exist?

To answer this question, it is necessary to examine the notion of a 'given' (Gegebenes). Meinong observes that generally nobody has any difficulty accepting that reality represents a 'given' to which our intellectual activity is directed, but we are less prepared to consider as a 'given' the objects of our aesthetic attitude, because the latter addresses without distinction both the real and the unreal, and aesthetic objects are the result of an arbitrary stipulation by the author; in short, we are not prepared to see a bond (Gebundenheit) beyond existence and nonexistence ${ }^{26}$. Now, if we consider theses (L1) and (L2), it follows that even if Mephistus neither exists nor has ever existed, he has some properties. Meinong develops such a thought from his own point of view: of objects such as Mephistus it is possible to affirm the so-being independently from the being - this is the principle of independence. Moreover, again according to Lipps, what Mephistus says, i.e. his answer to Faust, 'does not belong to the past, but to the immediate present'. For his part, Meinong assimilates this present to that which is

\footnotetext{
24 Cf. Meinong 1899: GA II, 382-383 (1978: 142).

25 Cf. Meinong 1899: $G A$ II, 383-384 (1978: 142).

26 Cf. Meinong 1905: $G A$ I, 600.
} 
expressed in the proposition 'the equilateral triangle has equal angles', which means that the present concerned is rather a timelessness - a characteristic peculiar to non-existing objects.

The action of a drama, even of a historical drama, does not have any strict time placement, at least not in absolute time, while it [the action] no more lacks relative time determination than its characters lack the past and also the future ${ }^{27}$.

Actually, not only is it difficult to identify the temporal (and spatial) determinations of a literary text (or of a symphony); it is also difficult to say what constitutes a literary work (or a symphony). Does it coincide with the original manuscript of the work (or of the score), or with every copy or authentic reproduction of the same? And what shall we say of ancient texts like Aristotle's Metaphysics or Machiavelli's Prince, whose originals are missing and whose copies differ on several points? The answer that Meinong suggests is that (M1) the being of a (literary or also musical) work is not existence at all, but it is a being which is disconnected from space and time, so that in certain circumstances the work can also be lost to humanity, but it can never be deprived of its own being. This audacious thesis is not free from difficulties.

In fact, if, as regards timelessness, abstract objects (such as geometric ones) and fictional aesthetic objects show some affinities, from an epistemological point of view it seems that there are none: while the proposition concerning the equilaterality of the triangle holds necessarily, the one concerning the words with which Mephistus addresses Faust does not possess the same character of necessity, because the words could have been different. This means not only that in the work of art arbitrariness holds sway, but that our knowledge of aesthetic objects, as it is mediated by the text, is of the same type as our knowledge of reality, that is empirical - despite the fact that such objects are unreal. But how is it possible to consider outside of space and time what can be known only empirically? Let us see how Meinong articulates his thought in response to the objection.

Here the creative activity of the artist comes into play, but we have to be quite clear about the concept of creation. If aesthetic objects do

27 Meinong 1905: GA I, 601. 
not exist, but are given outside of space and time, then they cannot even be created.

What the artist 'creates' is a more or less composite reality, that has the property, for those who apprehend it, to 'mean' something more or less composite, specifically the aesthetic object, which in this way, for those who apprehend that reality, is picked out from among the infinite totality of the objects outside of being and from whose viewpoint it can appropriately be designated as a predetermined object ${ }^{28}$.

The passage presupposes Meinong's semiotic theory presented in the second chapter of On Assumptions, according to which among linguistic signs, psychical experiences and objects subsist the three relationships of expressing, presenting and meaning. In short, linguistic signs (words and propositions) express experiences, that is, respectively, representations and judgments or assumptions; these mean objects, or more precisely representations mean objecta, judgments and assumptions mean objectives. Therefore, meanings are always objects; these are independent of the fact of being apprehended by experiences or expressed by signs, but they become meanings only if they are presented to the thought by the corresponding psychical experiences ${ }^{29}$. Presenting means offering an object to thought by a psychical experience $^{30}$. In this sense, the aesthetic object is the meaning, while the text is the sign of it.

Creation has to do with the material the artist uses, signs, not objects. The writer uses real material, words and propositions, in order to signify an object that is not real, the aesthetic object, which 'is picked out from among the infinite totality of the objects outside of being.' A thesis confirmed in On Assumptions:

objects cannot be made by us, but can only be chosen out of the infinite abundance of the objects outside of being (aus der unendlichen Fülle des Außerseienden $)^{31}$

${ }^{28}$ Meinong 1905: GA I, 603. Cf. also 1915: GA VI, 49 ff., esp. 52 fn. 1.

29 I have dealt with this subject in Raspa 2001. Cf. also Morscher 1973, Dölling 1998 and 2005, Simons \& Morscher 2001.

30 Cf. Meinong 1917: GA III, 291 (1972: 6) and passim; cf. also 1910: GA IV, 244 (1983: 177).

31 Meinong 1910: GA IV, 274 (1983: 197); my italics, the translation has been modified (V.R.). 
This is a consequence of a fundamental view of Meinong's, that is, that the object is always the logical prius ${ }^{32}$. That the aesthetic object is outside of being, explains those cases in which we do not have the original of a work, but a series of copies that diverge on individual points. Moreover, as Karl Schuhmann observed, such a view 'accounts for the fact that aesthetic properties need not be parts of real objects' and also explains the enjoyment of unreal objects, which we can only imagine, such as those of which literary texts speak; thus it explains aesthetic pleasure. But since the real object 'becomes an aesthetic object only indirectly, namely to the degree it is capable of directing us toward the aesthetic object itself' 33 , it would have the disadvantage of doubling the object of aesthetic experience, since it distinguishes between a real object and one outside of being. On the other hand, it seems that this is precisely the situation we are facing: we have a text, that speaks about something else, a story; the text and the story do not coincide; the point is to explain how they hold together. This is what Meinong does with the notions of predetermining reality and predetermined object.

Meinong's thesis is the following: representations and the real thoughts of the artist, which through real words and propositions arouse in the reader equally real representations and thoughts, mediate between the reader and the aesthetic object outside of being, whose knowledge and enjoyment, without such a mediation, would be denied to us. The objects of which a novel talks are genuine non-existing objects, and not representations in the author's mind that correspond to those of the reader; they enter nevertheless into relation with reality, and this relation consists in the 'being predetermined' of objects through something real ${ }^{34}$. The artist's thoughts, which are expressed in propositions, bring out the object from the Außersein, that is, they 'predetermine' it. This predetermination should be understood not as a 'determining previously', in a chronological sense, because Meinong maintains that the object is not created, but chosen; on the contrary, it is a logical predetermination or, if we prefer, a 'determining for' - for

32 Cf. Meinong 1917: GA III, 300-301, 354 (1972: 15, 62); 1921: GA VII, 22, $45,47$.

33 Schuhmann 2001: 534.

34 Cf. Meinong 1906-1907: GA V, 254. 
itself and for others ${ }^{35}$. The predetermining reality works as such not only as long as it exists, but from the moment in which it begins to exist, and also in the case in which the knowledge of such a function and therefore of the predeterminedness itself have been lost. That is, the predetermined object remains outside of being. The knowledge about the predetermined object has the character of an empirical knowledge, inasmuch as one reaches it only through the predetermining reality, which is of course empirical. But if the nature of an aesthetic object is knowable only empirically (a posteriori), on the basis of such knowledge - Meinong affirms - its nature can be then attributed to it analytically. In this way Meinong answers the objection raised above. What is deducible from the essence, from the so-being of an object, aside from the fact that the object exists or not, and even if the way through which we get to know it is empirical, assumes then an analytical character; it assumes this, not while we are getting to know the object, but after the cognitive process is concluded. Meinong's reasoning is similar to that introduced by Kant in the Prolegomena to any Future Metaphysics as regards the judgment 'Gold is a yellow metal'. According to Kant

all analytic judgments are a priori even when the concepts are empirical, as, for example, 'Gold is a yellow metal'; for to know this I require no experience beyond my concept of gold as a yellow metal. It is, in fact, the very concept, and I need only analyze it, without looking beyond $\mathrm{it}^{36}$.

Likewise - Meinong affirms - we know a diamond empirically, but once it is known, the property of being nonflammable can be attributed to it analytically; equally, through Faust we know Mephistus, and what he says results analytically from the empirically-known nature of Faust. The timeless present does not pertain to the predetermining reality - Goethe's thoughts - but to their object ${ }^{37}$. Therefore, an 'astonishing sovereignty of poetic or, more generally, artistic imagination' holds sway over fictional objects, nevertheless, once assumed - but we could also say stipulated - that a certain object possesses a certain property, it then has that property.

\footnotetext{
35 Cf. Meinong 1905: GA I, 604.

36 Kant 1783: Ak. IV, 267 (1997: 14-15).

37 Cf. Meinong 1905: GA I, 603.
} 
So, for example, in modern drama, exact information is frequently given as to the age or other properties of the characters in the play. At first this information can only be of the order of assumptions. But once such assumptions are made, the characters in question are indeed of the indicated age, as if the playwright were free to do with them as he wished. He has, in fact, nothing beyond the right to make analytic judgments in Kant's sense, according to which the gold mountain is in fact (tatsächlich) made of gold. In respect to these rights of poets, being is at disadvantage in relation to so-being 38 .

Predeterminedness not only pertains to aesthetic objects; actually, 'every written or spoken discourse predetermines an object, certainly every thought, whether or not it is expressed in words' 39 . Our judgments about the world correspond to choices. When we formulate a judgment and express it in a proposition, we do nothing more than make a figure emerge from a background of innumerable figures. If I look before me and I say 'the bookcase is full, I need another one', I bring out a state of affairs, but what I see is much more. I could say what the bookcase is like, what wood it is made of, what colour, that one book is standing, another lying flat, and so on. The states of affairs, or the objectives (in Meinongian terms), are infinite if we consider all the properties, both positive and negative, that the individual objects in the bookcase possess ${ }^{40}$. In this sense, the predeterminedness can also be lost; this does not change anything as regards the given of the object, that is of the objective.

On the basis of the fact that predeterminedness proceeds with absolute predominance and is conditioning both for the subject who predetermines a certain object and for those people whose intellectual activity is connected to this subject, Meinong speaks about an analogy between fictional aesthetic objects and definitions: in both cases there is a freedom in the predeterminedness that, once made, turns into a bond; in both cases the predetermined object remains outside of being; if the definition expresses the analiticity, then it is a judgment; if it

38 Meinong 1917: GA III, 374 (1972: 80); the translation has been modified (V.R.).

39 Meinong 1905: GA I, 604.

40 Meinong shares the Kantian principle of complete determination; cf. Kant 17811-17872: A 571-572 = B 599-600; Meinong 1915: GA VI, 168 ff.; cf. also Haller 1986: 76. 
takes part in 'forming' a fictional aesthetic object, then it is an assumption ${ }^{41}$. Leaving aside the cases in which determining object and determined object seem to coincide, as in the case of an architectural construction or a natural landscape, in substance 'the true object of an aesthetic attitude is not at all touched, at least theoretically, by the existence of reality, but nevertheless it reveals that peculiar rigid immutability [Unabänderlichkeit] of the predetermined object' ${ }^{42}$, an immutability which is connected to timelessness.

Before concluding this first part of my paper, something more on Außersein should be said. What is it? It is the sphere of the pure object, in which its existence or non-existence, possibility or impossibility has been put in brackets. Certainly, the properties of an object can be indicative of its being: 'an absurd object such as a round square carries in itself the guarantee of its own non-being in every sense' 43 ; nevertheless, if we leave aside, as in the case of the objects of stories, their determinations of being and consider only those of so-being, the Außersein belongs to all objects, not only to fictitious, absurd or eccentric ones, but also to those that exist and that subsist ${ }^{44}$. Außersein embraces therefore all that is 'given', that is all possible combinations among properties and objects ${ }^{45}$. For example, Meinong says:

besides the factual objective 'Pitch is black,' there are (in the sense of Außersein) also objectives such as 'Milk is black'46.

In both cases we are combining two objecta into an object of higher order, which is the corresponding objective of so-being. It is not then such an eccentric idea: in Death Fugue [Todesfuge] by Paul Celan we

\footnotetext{
41 Cf. Meinong 1905: GA I, 605; 1910: GA IV, 274 (1983: 197-198).

42 Meinong 1905: GA I, 605.

43 Meinong 1904: GA II, 493 (1960: 86).

44 Cf. Meinong 1917: GA III, 306 (1972: 19); 1921: GA VII, 21 (1974: 228). An exception is constituted by defective objects (defekte Gegenstände); cf. Meinong 1917: GA III, 304-309 (1972: 18-22); Jacquette 1996: 37 ff.

45 Cf. Meinong 1904: GA II, 492-493, 500 (1960: 85, 92); 1910: GA IV, 80 (1983: 62); 1915: GA VI, 181.

46 Meinong 1910: GA IV: 277 (1983: 199-200).
} 
read: 'Black milk of daybreak we drink it at evening / [...] Black milk of daybreak we drink you at night' 47 .

To have a more plastic idea of Außersein, we can think about Borges' Library of Babel, which records all possible combinations of the twenty-two letters of the alphabet plus the space, the comma and the full stop; note: not everything possible, but all possible combinations, therefore also those that are eccentric, bizarre and contradictory. These are the axioms on which the Library is founded:

'First: The library exists ab eterno', that is, it has not come into existence in a certain moment, nor it will end - just like what is outside of being. 'Second: The orthographical symbols are twenty-five in number' 48 (the space, the full stop, the comma and the twenty-two letters of the alphabet), and it also contains eccentric books, such as the one which repeats the letters M C V from the first line to the last; - the analogue is given by the theory of objects of higher order and by the principle of the obligatory infima, with the difference that these are not in a defined number like that of the Library, even though all that is apprehended can also be expressed in linguistic signs, that is with the twenty-five orthographic symbols.

'This much is already known: - affirms Borges - for every sensible line of straightforward statement, there are leagues of senseless cacophonies, verbal jumbles and incoherences'49. - As regards Meinong, we have eccentric and contradictory objects.

From the axioms on which the Library is founded one can deduce that: 'in the vast Library there are no two identical books', which means that 'the Library is total and that its shelves register all the possible combinations of the twenty-odd orthographical symbols' 50 - the whole infinite abundance (die unendliche Fülle) of the objects outside of being 51 .

\footnotetext{
47 Celan 1952/1983: 41-42 (2001).

48 Borges 1956: 87 (1962).

49 Borges 1956: 88 (1962).

50 Borges 1956: 89 (1962).

51 Borges adds: '(a number which, though extremely vast, is not infinite)', the same does not hold for the Außersein.
} 
'I repeat: - it suffices that a book be possible for it to exist. Only the impossible is excluded - explains Borges -. For example: no book can be a ladder, although no doubt there are books which discuss and negate and demonstrate this possibility and others whose structure corresponds to that of a ladder'52. - Also for Meinong impossible objects do not exist, but are outside of being, and yet people talk about them, which means that they too belong to the 'given'.

If a representation or a thought could have an object only if this object were something which is, i.e. which exists or subsists, then those representations and thoughts that are not directed to beings (as in the case of literary fiction), would have no object at all; but this contradicts intentionality thesis, so strongly assumed by Meinong that it excludes the possibility of a pseudo-relation in the case of fictitious entities. The solution proposed by Meinong is to cut the bond between objectuality and existence or being; this can be done if the object is considered as outside of being 53 .

3. Having ascertained that the aesthetic object is not the real object - the text - but rather the object outside of being - that is, the meaning of the real object -, we return to the question: how can something unreal like a fictional object arouse real emotions and feelings? Inasmuch as it enters into connection with real objects, that is with the material that, manipulated by the artist, constitutes the work of art. Explaining how this is possible implies the answer to the second question: what kind of objects are fictional aesthetic objects? As concerns literary texts, Meinong's thesis is that (M2) the true fictional aesthetic objects are objectives ${ }^{54}$, which are apprehended by assumptions.

In a certain sense we have anticipated this answer in our brief outline of Meinong's semiotic theory: texts are made up of words and propositions, which mean objecta and objectives, which take on the role of meanings, in that they are presented either by representations or by judgments and assumptions. Below I will speak about psychical

52 Borges 1956: 93 fn. 1 (1962).

53 Cf. Meinong 1910: GA IV, 233-234 (1983: 170).

${ }^{54}$ Cf. Meinong 1910: GA IV, 318, 319 (1983: 227, 228); 1917: GA III, 372 (1972: 79). 
experiences and aesthetic feelings not because these are the direct subject of my discourse, which focuses instead on ontological questions, but because the psychological treatment constitutes, according to Meinong, the access route to the ontological treatment of aesthetic objects: we have said that the way we approach aesthetic objects is empirical, only later can we pass over to the aprioristic treatment; the thesis should be proved through the analysis of the empirical material that puts us in contact with aesthetic objects, that is then the only material which is in first place accessible to us.

Let us first of all define assumptions, relating them to judgements and representations. Judgment possesses the two moments of conviction and position, which means that it claims truth and is either affirmative or negative; besides this, it also needs representations as its essential fundaments, because every event of the psychical life, which is not itself a representation, presupposes the representing 55 . Assumptions occupy an intermediate position between representations and judgments ${ }^{56}$ : they are affirmative or negative like judgments, but without claiming truth like representations ${ }^{57}$. Assumptions are expressed by interrogative, optative, and imperative propositions, by subordinate clauses (daß-Sätze) that occur in propositions such as 'I fear, I suppose, I contend that $p^{\prime 58}$, in hypothetical reasoning, in lies, in games and in narrative works. In all such cases the conviction that the object exists is not required.

According to Meinong, also our attitude toward the aesthetic object does not demand at all the belief that it exists. Previously, he had maintained that our aesthetic attitude is based above all on representing, because the judgment has as its peculiarity the moment of conviction; but he decidedly changed his mind when he discovered assumptions which, insofar as they lack the moment of conviction, can take the place of judgments and express objectives that - as we have said - are

55 Cf. Meinong 1902: 1-3, 256; 1910: GA IV, 1-4, 46, 339 (1983: 9-11, 39, 242); 1917: GA III, 290, 294 (1972: 6, 9).

56 Cf. Meinong 1902: 277; 1910: GA IV, 367 (1983: 262).

57 Cf. Meinong 1902: 257; 1910: GA IV, 3, 340, 368 (1983: 10, 242, 262-263); 1921: GA VII, 33.

58 Cf. Meinong 1902: 26 ff.; 1910: GA IV, 33 ff. (1983: 30 ff.) 
also objects of aesthetic feelings, for whose expression representations are therefore inadequate. Hence the value attributed to assumptions. In On Assumptions there are different arguments to support the aforesaid thesis, i.e. that (M2) the true aesthetic objects are objectives and that these are apprehended by assumptions. I will introduce three of them; the first dates back to the first edition (1902), the others appear in the second (1910).

The first argument (M2a) concerns the assumptions themselves. These occur - as we said - in the cases of fiction, within the realm of 'as if', and conspicuously in lies, in games and, as far as we are interested, in $\operatorname{art}^{59}$. There is a close analogy between the game of the child, who 'pretends' (fingiert) or 'imagines' (sich einbildet) to be somebody else, and art, particularly the art of acting. But, if we consider the point of view of the writer, he too, while creating the work, puts himself in the place of all the people he represents; sometimes he tells true stories, but what he mostly deals with is fiction and 'fiction is just assumption' 60 . Let us now put ourselves in the reader's place: what happens to the reader reading a story he does not believe, because he knows that the story never happened? Although not believing it, while reading he makes the same assumptions as the narrator; obviously, this does not exclude an elaboration of the material assumed by the reader. Certainly, as I said above, the narrator does not express only assumptions, but he can also express true judgments; the effect on the reader is often however identical and even if the narrator enunciates truths, the reader does not have to accept them as they are. Anyway, Meinong concludes, we stay on the level of assumptions ${ }^{61}$. Subsequently, in $O n$ Emotional Presentation [Über emotionale Präsentation] (1917), Meinong develops a distinction that accounts for this difference, distinguishing between 'shadowy' assumptions and assumptions that are similar to judgments. I will not discuss this matter here, as I will not deal with the indeterminedness of fictional objects, even if discussing them would help to give a more complete picture of the whole matter62.

\footnotetext{
59 Cf. Meinong 1902: 36-37; 1910: GA IV, 107 (1983: 81).

60 Meinong 1902: 45; 1910: GA IV, 115 (1983: 86).

61 Cf. Meinong 1902: 57-60; 1910: GA IV, 127-130 (1983: 94-97).

62 But cf. Raspa 2001 and 2005b.
} 
For our purposes, two points are fundamental: first, wherever there are assumptions, there are objectives too ${ }^{63}$, because objectives are the objects of assumptions, as of judgments; and since in literature we are dealing primarily with assumptions, though judgments are not excluded, objectives are the true aesthetic objects of narrative works; the second point is that assumptions play a prominent role in art $^{64}$, since our attitude toward aesthetic objects does not demand at all the conviction that these exist, and indeed the objectives that occur in art works are not generally believed, but assumed.

The second argument (M2b) examines the representations. Those expressed in a literary text are produced or imaginary representations, at most they can be reproductions 65 ; in every case we are dealing with composite representations, to which correspond, from an ontological point of view, objects of higher order, that is complexes ${ }^{66}$. But an objective is implicit in every complex; therefore, to grasp a fictional complex we need to grasp the objective implicit in it. The reasoning which supports this thesis was suggested to Meinong by Russel167: in the object of the form ' $\mathrm{A}$ and $\mathrm{B}$ in the complex $\mathrm{C}$ ' there is already present an objective of the form 'the complex that is constituted by A and B', or 'A, which with B constitutes a certain complex', even if the form tends to hide it. So 'where there is a complex, there is also an objective as an integrating factor in it, and one who wants to apprehend the complex cannot do it otherwise than by apprehending the objective' 68 . That is why representing is not sufficient to apprehend objects of higher order, whether they are objects or objectives, but assuming is the most suitable experience to apprehend aesthetic objects, and again it follows that these are mainly objectives.

This thesis (M2), which Meinong maintains in the first edition of $\mathrm{On}$ Assumptions and reasserts in the second, is firmly opposed by Stephan Witasek, one of Meinong's pupils, who in his Outlines of General

\footnotetext{
63 Cf. Meinong 1910: GA IV, 131 (1983: 98).

64 Cf. Meinong 1902: 210-211; 1910: GA IV, 168-169 (1983: 124).

65 Cf. Meinong 1910: GA IV, 11, 16, 377-378 (1983: 15, 18-19, 269).

66 On this cf. Raspa 2005a.

67 Cf. Russell 1904/1973: 50 ff.

68 Meinong 1910: GA IV: 280 (1983: 202).
} 
Aesthetics [Grundzüge der allgemeinen Asthetik] (1904) developed a structured theory which, though it agrees on the whole with Meinong's view, diverges from it concerning the role of objectives and assumptions $^{69}$. But before discussing Witasek, let us briefly examine the third argument (M2c) by which Meinong answers the question about the effects of aesthetic objects.

(M2c) According to Meinong, besides intermediate mental facts between representations and judgments, that is assumptions, there are also intermediate mental facts between representations and feelings, such as the feelings related to works of art, which Meinong calls 'phantasy-feelings (Phantasiegefühle), ' and which arise for example when a tragedy evokes fear or compassion ${ }^{70}$. As assumptions resemble judgments in virtue of the opposition of affirmation and negation, but they are not judgments, so phantasy-feelings are feelinglike in virtue of the opposition of pleasure and displeasure, but they are not real feelings. At the theatre the spectator does indeed experience something in himself, for example something similar to compassion, which however is not literally compassion. The compassion for the tragic heroine Margaret is not only of a lower degree, but even qualitatively different from the compassion that I feel for an unhappy girl whose sad tale I know $^{71}$. It is necessary to distinguish between phantasy-feelings and aesthetic feelings, which are genuine feelings, for instance aesthetic enjoyment. Indeed, phantasy-feelings, together with assumptions, play a fundamental role in the arousal of aesthetic feelings. From reading works of art arise also phantasy-desires (Phantasiebegehrungen), as when one wishes a novel to end in a certain way, and also these are no more genuine desires than phantasy-feelings are genuine feelings. The presuppositions for such mental phantasy-experiences are assumptions, which are expressed by the propositions of the work, but they

${ }^{69}$ A reading of Witasek's aesthetics is given by Smith 1996 and Schuhmann 2001. According to Schuhmann (2001: 518), 'Witasek's theory is based on Meinong's early general theory of value as worked out mainly in Meinong's PsychologicalEthical Investigation on Value Theory from 1894.' Cf. also Schuhmann 2001: 533.

70 Cf. Meinong 1910: GA IV, 309 (1983: 221).

71 Cf. Meinong 1910: GA IV, 312, 316-317 (1983: 223, 226). 
refer to objectives ${ }^{72}$. Therefore, assumptions go beyond the intellectual sphere and extend to the emotional one; it follows that objectives belong also to phantasy-feelings and phantasy-desires. Hence, since objectives considered as aesthetic objects arouse in us feelings and emotions, they are also often objects of our emotional activity.

Witasek recognizes the value of objectives, but he does not believe that they are aesthetic objects ${ }^{73}$. Like Meinong, Witasek believes that objectives play a fundamental role in the narrative arts, since novels, plays and poems are composed of propositions and, to understand and enjoy a literary text, it is necessary to understand the objectives meant by propositions ${ }^{74}$. Certainly, objects of representation also play their part, because no objective can subsist without objecta, but they play a more indirect role, since every reader imagines what is described differently, nor is it necessary that he should imagine it in a distinct way. The main role is played by situations, events, narrated facts and, along with them, by the relations subsisting between the characters and objects of the story. 'But these are objectives, not objects of representation'75. What has aesthetic effectiveness in a literary work is in the first place its content, and this is constituted by the meanings of the single propositions which - as we know - correspond to objectives. Nevertheless, Witasek maintains that (W1) 'objectives are not, as it appears at first sight, the genuine aesthetic objects, on the contrary they are mediators of aesthetic objects' 76 . If we mean by 'aesthetic object' what our feeling of pleasure and displeasure is directed to, then, since this feeling is never directed to an objective, which is neither beautiful nor ugly, the objective cannot be an aesthetic object. The

\footnotetext{
72 Cf. Meinong 1910: GA IV, 313-315 (1983: 224-225).

73 At first, Witasek (1904: 53 ff.) puts objectives in the class of the so-called 'aesthetic elementary objects (ästhetische Elementargegenstände),' that is objects 'whose aesthetic qualities do not come down to the sum of the aesthetic qualities of the components of the object, but belong only to the object as a whole and are lost when one analyses it' (p. 35); however, after a careful critical examination briefly presented above - , he excludes them (p. 179).

74 Cf. Witasek 1904: 56.

75 Witasek 1904: 57.

76 Witasek 1904: 167-168; my italics (V.R.).
} 
aesthetic quality, the beauty of a literary work depends not only on its language and style, but undoubtedly on its content, and finally on the objectives in which it consists, since those who do not understand the content of a work cannot say they have enjoyed it. Yet, an objective is not beautiful in itself, but it is mediator of beauty. The aesthetic properties of a work depend on objectives, 'as the perfume of flowers on the wind that blows' 77 , says Witasek.

Witasek distinguishes an epistemological level and an aesthetic one. An objective contains the objects of representations and it serves to describe facts and situations, in which - to put it colloquially - we always speak about people and things. The objective is therefore fundamental for the understanding of the work, since understanding a work - as aforesaid - means understanding the objectives of the propositions that compose it. Nevertheless the aesthetic effectiveness of an objective depends on the words and the representations through which it is communicated to the subject or thought by him; and only if words and representations have aesthetic properties, do objectives also possess them, but only indirectly. What counts is the choice of the expressions, their position, etc. ${ }^{78}$. To demonstrate this, Witasek advances two arguments.

(W1a) First of all, for the aesthetic effect it is important how an objective is expressed. Witasek therefore invites us to transform a line of poetry into a non poetic form but with the same meaning, i.e. the same objective - in short, to translate it into prose: naturally the line loses all aesthetic value. The aesthetic properties of the saying 'youth is a garland of roses, old age a crown of thorns', depend on the words and the representations expressed by them. If we paraphrase it in this way: 'In youth life is easy, happy and cheerful, in old age difficult and lacking in pleasures, but in exchange it is venerable', the objective loses aesthetic effectiveness. (Leaving aside the additions, Witasek believes that the two propositions express the same objective.) The thought of the objective enriches the material of representation and hence the material which arouses aesthetic feelings in us, but the objective is not the direct object of our aesthetic attitude ${ }^{79}$.

77 Witasek 1904: 169.

78 Cf. Witasek 1904: 170-171.

${ }^{79}$ Cf. Witasek 1904: 171-173. 
(W1b) The second argument put forward by Witasek to show that objectives are only mediators pertains to feelings, which are in the case of the narrative arts above all empathy-feelings (Einfühlungsgefühle) and sympathy-feelings (Anteilsgefühle). The former are feelings through which a person who reads, for instance, the scene of 'Margaret in jail' feels with the heroine what she feels: torment, confidence, pious resignation, desperation; while the latter are the liking and the compassion that the reader feels for Margaret. In the first case, the subject reproduces in himself the psychical life of the object (Margaret), in the second he reacts emotionally to the object ${ }^{80}$. These feelings occur where there are objectives, which again act as mediators: through them feelings are aroused in fact in the reader, and only inasmuch as the objectives do this, do they have aesthetic effectiveness ${ }^{81}$ - which, as we know, depends on the words and the objects of representations. Moreover, if the feeling of aesthetic pleasure were immediately directed at the objectives, then judgments and assumptions should be the presupposition of such a feeling, but judgments and assumptions Witasek maintains - play such a role in the case of value-feelings (like loving, appreciating, honouring) and knowledge-feelings (doubting, understanding); if they were the presupposition of aesthetic feelings too, the difference between the former and the latter would disappear. This difference consists not in the fact that value-feelings are based on the real world, and phantasy-feelings on the world of imagination; on the contrary, phantasy-feelings are also real, they are characterized by the specificity of their presupposition, namely assumptions, so they are always assumptive feelings ${ }^{82}$. Not only, but often assumptions too can act as premises for value-feelings, as when I imagine that I can lose my brother and I regret it; in this case, we have a phantasy-feeling of value. Equally it is not excluded that a judgment can arouse aesthetic feelings. The difference between value-feelings and aesthetic feelings lies in the fact that the former have objectives as object, while the latter have objecta, that is the objects of representations.

80 Cf. Witasek 1904: 148-149. On empathy-feelings and sympathy-feelings cf. Smith 1996: $220 \mathrm{ff}$.

81 Cf. Witasek 1904: 174-175.

82 Cf. Witasek 1904: 120-121 fn.. 
The aesthetic attitude is not directed to objectives at all, but primarily to the objects of representation that they communicate (vermitteln) to the subject ${ }^{83}$.

Witasek's thesis (W1) is diametrically opposed to Meinong's thesis (M2); we see now how the latter answers the criticisms. A part of Meinong's reply (MR) to Witasek's first criticism (W1a) is already implicit in the second argument we have seen above (M2b), that is, that objectives are implied in the complex objects of representations. (MRW1a) As regards language, Meinong argues that, indeed, after having transformed a poem into prose, there is very little poetry left in it; the question is, however, whether this transformation has not also changed the objective. One who confers aesthetic dignity on a certain objective, neither sees it deprived of its objectum-material, nor expressed in a passing form, where within certain limits there is no modification of the material. Rather, the aesthetic significance is dependent on the determinations of the real material, and precisely on those referred to by Witasek. The fact remains however that, for the reasons rehearsed above, the true aesthetic object is the objective ${ }^{84}$. Meinong maintains therefore a close relationship between objective and the linguistic form that expresses it - paraphrase is not admitted in poetry -, but he does not say anything to explain this thesis, leaving the reader disappointed. For instance, the problem of translation remains open, a problem that the theory of objectives on the other hand seems to face; besides, Meinong himself maintains that the same objective can be expressed in different forms: 'A exists' is equivalent to 'the existence of A'85.

As regards Witasek's second argument (W1b), Meinong's reply is structured in two parts. (MR-W1b') Firstly, he contests the equality between phantasy-feelings and assumptive feelings, as well as the notion that phantasy-feelings are real feelings. Now, that they are not real feelings is shown by the fact that - as we said - the compassion towards Margaret is both of lower degree and qualitatively different from the compassion for an unfortunate girl who is really living. That they are not simply assumptive feelings can be deduced from the

\footnotetext{
83 Witasek 1904: 179.

84 Cf. Meinong 1910: GA IV, 318-319 (1983: 227-228).

85 Cf. Meinong 1910: GA IV, 56 (1983: 46); 1915: GA VI, 27-28 and fn. 3.
} 
consideration that many phantasy-feelings are not founded on assumptions, as when we remember a strong toothache or a person's death; therefore, the sphere of assumptive feelings is narrower than that of phantasy-feelings ${ }^{86}$. The second part of the argument (MR-W1b") is far more important. Witasek believes that feelings which have objectives as their object can only be value-feelings, not aesthetic feelings. Now, according to Meinong, value-feelings are always directed to being, in the first place to existence, obviously also to the existence of something that is thus and so, to its properties, in every case to existence. This does not hold for aesthetic feelings: they always bear on sobeing, accidentally also on the so-being of something existing, and this so clearly that the kind of treatment from which they arise can be considered existence-free (daseinsfrei). This point of the existence-freedom (Daseinsfreiheit) is fundamental: whether something exists or not is never a concern of the aesthetic attitude, rather the converse happens, that is, that something which can also exist is thus and so; instead, value-feeling is always turned toward an existing thing, even if it is determined in a certain way. Hence, against Witasek, the essence of value-feelings does not depend on judgment and assumption, but always on the nature of the objective. If feeling is directed to the being, it is a value-feeling, if it is directed to the so-being, it is an aesthetic feeling. Certainly, there are value-feelings that are directed to objecta such as a color or a form, and not to objectives, but an objective of sobeing is implicit in qualitative determinations ${ }^{87}$. It follows that every aesthetic feeling is directed to objectives, if not explicitly, at least implicitly 88 .

It is evident that the contrast between the two authors on the role of the objective, which was underlined with the opposition of (W1b) and (MR-W1b), depends on different conceptions (here very briefly sketched) as regards feelings in their various forms. I do not intend to develop this matter further, which - as aforesaid - is not specifically of an ontological character; I wanted however to mention it, because, according to both authors, in this way one comes to speak of aesthetic objects.

86 Cf. Meinong 1910: GA IV, 316-317 (1983: 226-227).

87 Indeed, as we saw above (M2b), an objective is always implicit in a complex. 88 Cf. Meinong 1910: GA IV, 319-320 (1983: 228-229). 
4. Hitherto we have spoken of aesthetic objects as a proper class of fictional objects, now the question arises of their specificity relative to fictional objects in general, insofar as it is obvious that not all fictional objects are also aesthetic objects. So we come to the third question: what makes a fictional object an aesthetic one? And here another point of divergence between Meinong and Witasek emerges, perhaps even more fundamental than the previous one: (W2) aesthetic objects are not objects of higher order. This thesis, if proven, would significantly reduce the claims to universality of the object theory as regards aesthetic objects: objects of higher order are both objectives and objects of phantasy-representations, that is complexes.

In the Outlines of General Aesthetics, Witasek states that 'an object becomes an aesthetic object, if it is bearer of aesthetic properties' 89 . Of these the most characteristic is 'beauty', which, like the others, 'proves to be not a real property of its bearer, but an ideal one' 90 . The beauty of a picture, indeed, is not perceivable as the picture and the masses of colour are; if we listen to a melody or a poem, we hear sounds or words, but beauty consists neither in the individual sounds or words nor it is added as something existing alongside them. Moreover, beauty is not an objectual property of the object, that is, a property which, like real properties, is represented together (mitvorgestellt) with the representation of the object and can then describe it: for example, the colour is an objectual property of the picture but the similarity of this with a copy is not.

So beauty is also an extra-objectual determination of its bearer, though rightly it is designated as a property of the latter; even a representation, however complete, of an object does not need to contain the thought of beauty, at least insofar as it intends to be only the representation of this object ${ }^{91}$.

Again, in the Outlines of General Aesthetics Witasek had said that an object is aesthetic when it is the object to which our feeling of pleasure and displeasure is directed, a definition that obviously depends on that given above.

\footnotetext{
89 Witasek 1904: 27.

90 Witasek 1904: 14.

91 Witasek 1904: 15-16.
} 
In his last writing, 'On Aesthetic Objectivity [Über ästhetische Objektivität]' (1915), as regards aesthetic judgment, 'This (object) is beautiful (not beautiful, ugly, etc.)', Witasek maintains that

In making the judgment ' $\mathrm{A}$ is beautiful', one is not normally thinking about a relationship of A with the subject, with their emotional reaction, nor about this same emotional reaction; one means a property of A, that is entirely in the same object A. ${ }^{92}$.

If we call the object A 'substratum', we can say that the aesthetic object consists in this substratum taken together with the aesthetic properties. The bearer of these qualities is not however the transcendent real (existing) object, but the immanent (pseudo-existing) object, and likewise aesthetic properties are only an objectual part of this immanent object. Witasek expressly denies that the bearer can be an existing or subsisting object, insofar as he believes that the evidence of certainty regarding aesthetic judgment holds only for the immanent object $^{93}$. The essential characteristics of an aesthetic object are the non-independence (Unselbständigkeit) from the substratum, which means that the being of an aesthetic object is founded on the being of another or other objects, and the dependence (Abhängigkeit) on variations of the substratum. An aesthetic property such as 'beautiful' requires indeed not only, like the property 'red', a substratum to belong to, but also a property or a complex of properties as its basis, without which it could not be and on whose nature it is dependent. Indeed, if one or more elements of the substratum change, the object can change from beautiful to ugly. Changing some notes of a melody, for instance, it can become less beautiful or even ugly 94 . This dependence is unidirectional in the sense that the aesthetic property is dependent on the substratum and on its properties, not vice versa. This specific dependence relation makes the difference between aesthetic properties and sensory properties: the colour red needs an extension, but it does not vary with the variations of the latter; furthermore, while the aesthetic property can vary if sensory properties like colours vary, the converse does not hold. However, a short consideration will bring out evident

92 Witasek 1915: 91-92.

93 Cf. Witasek 1915: 94, 96-98.

94 Cf. Witasek 1915: 105, 108, 110-112. 
analogies between aesthetic properties and objects of higher order such as, for example, similarity. Indeed, similarity does not occur without similar objects; moreover, whether, and to what extent, two objects are similar, depends on the nature of the objects. Therefore aesthetic properties seem to be ideal objects of higher order ${ }^{95}$. But four factors lead us to exclude this possibility. Witasek is speaking only of beauty, but his discourse can also be extended to other aesthetic properties.

First of all, (W2a) thinking back to the example of similarity, Witasek observes that this is between the two members, for example red and orange, with which it builds a complex; beauty is instead on the red-orange complex: if the difference is removed, the two colours are each for itself, while if beauty is removed, the complex remains. Besides, (W2b) beauty does not need a plurality of inferiora, as objects of higher order do, but a unity that can be, in turn, both complex and simple; for objects of higher order, though, being based on a unity is a limiting case (that of identity) ${ }^{96}$. In third place, (W2c) objects of higher order are tied to their inferiora by a bond of aprioristic necessity: given red and orange, they are necessarily different or similar (according to their gradation); while there is no necessity relationship between the two colours and beauty. Finally, (W2d) difference is not thinkable intuitively (anschaulich), while beauty is intuitively apprehended through its bearer (melody, picture, poem); in other words, the difference between two empirical objects is actively produced by the subject through an operation of comparison, the beauty of a perceptive object is instead passively accomplished. For all these reasons, beauty cannot be considered as an ideal object of higher order ${ }^{97}$. But if beauty is not something real close to the object, and it is not an ideal object of higher order, then it neither exists nor subsists. Hence, there must be either a new class of objects which have till now not been contemplated by object theory, but which subsist objectively like ideal objects of higher order, or a third type of being, which Witasek does not identify with the Außersein, but with the immanent being ${ }^{98}$.

\footnotetext{
95 Cf. Witasek 1915: 112-114.

96 Cf. Meinong 1899: GA II, 394 (1978: 149).

97 Cf. Witasek 1915: 180-183.

98 Cf. Witasek 1915: 191-192, 198.
} 
If the later Witasek is right, much of Meinong's theory concerning aesthetic objects comes apart. It is therefore absolutely necessary for him to reply to his friend and pupil. He does so by accepting the first part of Witasek's discourse, according to which an aesthetic object is non-independent of being and dependent on the so-being, and rebutting the criticisms made by him ${ }^{99}$. However, Meinong does not answer each of the four criticisms separately, but he develops a single argument, in which he examines the first two, of a strongly ontological character, while he replies very quickly to the last two (of a gnoseological character), concerning the lack of aprioristic necessity and of productive activity.

Meinong faces the main theoretical difficulty raised by Witasek against the thesis according to which (M3) aesthetic objects are objects of higher order, more precisely they are complex bearers of beauty, that is, the oneness (Einsheit) of the substratum required by aesthetic properties (as W2a and W2b maintain). I note in advance that Meinong identifies Witasek's error as his having considered objects of higher order only from the point of view of objecta, and not also from that of objectives. His refutation (MR-W2a-b) can be divided into three steps:

(1) objectives are also objects of higher order;

(2) there are objectives that are not based on a plurality of inferiora; therefore,

(3) if not all objects of higher order need a plurality of inferiora,then there is no difficulty in considering aesthetic objects as objects of higher order.

Let us examine the argument in detail.

(1) The theory of objects of higher order was initially formulated from the point of view of objecta, but also objectives are objects of higher order. For instance, compared to the objective 'A is B,' 'it is a fact that $\mathrm{A}$ is $\mathrm{B}$ ' is an objective of higher order. Hence, 'each objective is an objective of higher order with respect to another objective if the latter occupies the place of the objectum in the former' ${ }^{\prime 00}$. The objective is

\footnotetext{
99 Cf. Meinong 1917: GA III, 387-388 (1972: 92-93).

100 Meinong 1917: GA III, 389 (1972: 94).
} 
also an object of higher order with respect to the objecta of which it is constituted, like the objective 'A is B' with respect to the objecta A and $\mathrm{B}$; therefore, 'all objectives as such are objects of higher order' 101 .

As regards the height of order, it holds that objects of higher order are built on objects of lower order in such a way that the former could not be there, if the latter were not there at first. The 'at first' indicates a logical priority, not a chronological one. This holds both for objecta and for objectives. An objective is necessarily based on some material, which may, in its turn, contain other objectives, but these are ultimately based on objecta. That means that objectives can never occupy the position of infima.

(2) Relations and complexes certainly require at least two elements; the same holds for objectives of so-being of the type 'A is B'; but objectives of being ('A is'), of existence ('A exists'), of subsistence (even of Außersein) are monadic by nature, and it does not make any difference that they can be based both on a simple and on a complex substratum of objecta. This being so, it is wrong to extend to all objects of higher order a characteristic that is common to relations and complexes, that is, that they need a plurality of inferiora ${ }^{102}$.

(3) If not all objects of higher order need a plurality of inferiora, the main obstacle to considering aesthetic objects as objects of higher order, that is the oneness of substratum, no longer subsists. Their dependence on the substrata is a sign - just as Witasek showed - of the superius character of aesthetic objects, which - Meinong concludes 'are indeed subsumable under the notion of objects of higher order' 103 .

As regards Witasek's criticism of a gnoseological character (W2c and W2d), Meinong's reply is very short and also vague. Regarding the first, (RM-W2c) Meinong denies that the bond of aprioristic necessity between inferiora and superius is a proper character of all objects of higher order: leaving aside real complexes and relations, it would be enough to consider objectives concerning non-aprioristic knowledge ${ }^{104}$. As for the other criticism, (RM-W2d) Meinong replies simply

\footnotetext{
101 Meinong 1917: GA III, 390 (1972: 94).

102 Cf. Meinong 1917: GA III, 390-391 (1972: 95).

103 Meinong 1917: GA III, 391-392 (1972: 95).

104 Cfr. Meinong 1917: GA III, 391 (1972: 95)
} 
that the productive activity of the subject arises in apprehending objects of higher order in very different ways: if such productive activity cannot be disregarded in the comparative apprehension of a difference, it is however not noticeable with certainty in the apprehension, for instance, of a melody 105 .

Lipps made his criticisms from a point of view external to object theory, Witasek from an internal one; both acknowledge that fictional aesthetic objects have a kind of mental existence, which is denied by Meinong. For him fictional aesthetic objects do not exist, but they are disconnected from space and time (M1); besides, like all fictional objects, they are objectives which are apprehended by assumptions, or they require an objective, in that this is implicit in every complex representational objectum (M2); finally, they are specific objects of higher order, more precisely they are beauty-bearing complexes (M3).

To conclude, it should be specified that, despite the differences we have examined, Meinong's and Witasek's considerations do agree on many points. The divergences are the result of the different focus of their respective discourses: Witasek has the tendency to consider as aesthetic objects not only the objects of literature, but also those of music and of the visual arts - as the few examples given imply -, he lacks however a broader perspective, which he infers when necessary from Meinong; Meinong, on the other hand, concentrates almost exclusively on fictional objects (with some excursions into music), which he tries to frame within the wide compass constituted by the object theory. Insofar as the two demands are unifiable, both Meinong and Witasek developed only a part of the work.

\section{References}

Albertazzi, L., D. Jacquette \& R. Poli, (eds.) (2001), The School of Alexius Meinong, Aldershot/Burlington USA/Singapore/Sydney, Ashgate.

Barbero, C., \& V. Raspa (eds.) (2005), 'Il pregiudizio a favore del reale. La teoria dell'oggetto di Alexius Meinong fra ontologia e epistemologia', special number of Rivista di Estetica, n.s., 30, n. 3.

105 Cfr. Meinong 1917: GA III, 389 (1972: 93) 
Borges, J.L., (1956), Ficciones, in Obras completas, Buenos Aires, Emecé [English translation in Borges 1962].

- (1962), Labyrinths. Selected stories \& other writings, ed. by D.A. Yates \& J.E. Irby, Preface by A. Maurois, Norfolk (Conn.), Laughlin.

Brentano, F., (18741/1924-1928²), Psychologie vom empirischen Standpunkt, 2 Bde., Leipzig, Duncker \& Humblot, 18741'; 3 Bde., (ed.). von O. Kraus, Leipzig, Meiner, 1924-1928².

Celan, P., (1952/1983), Mohn und Gedächtnis, Stuttgart, Deutsche VerlagsAnstalt, 1952; in Gesammelte Werke, Erster Band, Frankfurt am Main, Suhrkamp, 1983, pp. 7-78 [English translation in Celan 2001].

- (2001), Selected Poems and Prose of Paul Celan, translated J. Felstiner, New York/London, Norton. 'Death Fugue' is available at http://osfl.gmu.edu/ /smithg/deathfugue.html.

Dölling, E., (1998), 'Zeichen und Annahmen. Alexius Meinongs zeichenphilosophische Untersuchungen', in Kodikas, 21, pp. 1-15.

- (2005), “... dieser Umweg führt über sprachliche Ausdrücke, durch die sich Annahmen verraten': Eine semiotische Sicht auf Meinongs Annahmenlehre', in Meinong Studies / Meinong Studien, 1, pp. 129-158.

Findlay, J.N., (19632), Meinong's Theory of Objects and Values, (1933¹) Oxford, Clarendon Press.

Grossman, R., (1974), Meinong, London/Boston, Routledge \& Kegan Paul.

Haller, R., (1986), Facta und Ficta, Stuttgart, Reclam.

Kant, I., (1781 $\left.1-1787^{2}\right)$, Kritik der reinen Vernunft, Riga, Hartknoch; in Ak. IIIIV.

- (1783), Prolegomena zu einer jeden künftigen Metaphysik, die als Wissenschaft wird auftreten können, Riga, Hartknoch; in Ak. IV, pp. 253-383 [English translation: Kant 1997].

- $\quad$ (1910 ff.), Kants gesammelte Schriften, hrsg. von der Königlich Preußischen Akademie der Wissenschaften, Berlin, Reimer; Berlin/Leipzig, de Gruyter \& Co., [abbreviated as $A k$.]

- Bd. III: Kritik der reinen Vernunft ( 2. Aufl. 1787), 1911.

- Bd. IV: Kritik der reinen Vernunft (1. Aufl.). Prolegomena. Grundlegung zur Metaphysik der Sitten. Metaphysische Anfangsgründe der Naturwissenschaft, 1911.

- (1997), Prolegomena to any future metaphysics, with an introduction by L.W. Beck, Upper Saddle River (NJ), Prentice-Hall Inc.

Jacquette, D., (1996), Meinongian Logic. The Semantics of Existence and Nonexistence, Berlin/New York, de Gruyter.

Lambert, K., (1983), Meinong and the Principle of Independence. Its Place in Meinong's Theory of Objects and its Significance in Contemporary Philosophical Logic, Cambridge, Cambridge University Press.

Lindenfeld, D.F., (1980), The Transformation of Positivism. Alexius Meinong and European Thought, 1880-1920, Berkeley, University of California Press. 
Lipps, Th., (1905), 'Weiteres zur 'Einfühlung", in Archiv für die gesamte Psychologie, 4, pp. 465-519.

- (1906), 'Über 'Urteilsgefühle”, Archiv für die gesamte Psychologie, 7, pp. $1-32$.

Meinong, A., (1899), 'Über Gegenstände höherer Ordnung und deren Verhältnis zur inneren Wahrnehmung', Zeitschrift für Psychologie und Physiologie der Sinnesorgane, 21, pp. 182-272; in GA II, pp. 377-471 [English translation: Meinong 1978].

- (1902), Ueber Annahmen, Leipzig, Barth (= Zeitschrift für Psychologie und Physiologie der Sinnesorgane, Ergänzungsband 2).

- (1904), 'Über Gegenstandstheorie', in Untersuchungen zur Gegenstandstheorie und Psychologie, hrsg. von A. Meinong, Leipzig, Barth, pp. 1-50; in GA II, pp. 481-530 [English translation: Meinong 1960].

- (1905), 'Über Urteilsgefühle: was sie sind und was sie nicht sind', Archiv für die gesamte Psychologie, 6, pp. 21-58; in GA I, pp. 577-614.

- (1906), Über die Erfahrungsgrundlagen unseres Wissens, Berlin, Springer (= Abhandlungen zur Didaktik und Philosophie der Naturwissenschaft. Sonderhefte der Zeitschrift für physikalischen und chemischen Unterricht, I, 6, pp. 379-491); in GA V, pp. 367-481.

- (1906-1907), 'Über die Stellung der Gegenstandstheorie im System der Wissenschaften', Zeitschrift für Philosophie und philosophische Kritik, 129, pp. 48-94, 155-207; 130, pp. 1-46; in GA V, pp. 197-365.

- (1910), Über Annahmen, zweite, umgearbeitete Auflage, Leipzig, Barth; in GA IV, pp. 1-389, 517-535 [English translation: Meinong 1983].

- (1915), Über Möglichkeit und Wahrscheinlichkeit. Beiträge zur Gegenstandstheorie und Erkenntnistheorie, Leipzig, Barth; in GA VI, pp. XV-XXII, 1-728, 777-808.

- (1917), 'Über emotionale Präsentation', Kaiserliche Akademie der Wissenschaften in Wien. Philos.-histor. Klasse, Sitzungsberichte, 183, 2. Abh.; in GA III, pp. 283-476 [English translation: Meinong 1972].

- (1918), 'Zum Erweise des allgemeinen Kausalgesetzes', Kaiserliche Akademie der Wissenschaften in Wien. Philos.-histor. Klasse, Sitzungsberichte, 189, 4. Abh.; in GA V, pp. 483-602.

- (1921), 'A. Meinong [Selbstdarstellung]', in Die deutsche Philosophie der Gegenwart in Selbstdarstellungen, mit einer Einführung hrsg. von R. Schmidt, Leipzig, Meiner, Bd. 1, pp. 91-150; in GA VII, pp. 1-62 [Partial English translation: Meinong 1974].

- (1960): 'The Theory of Objects', translated by I. Levi, D.B. Terrell, and R.M. Chisholm, in Chisholm, R.M. (ed.), Realism and the Background of Phenomenology, Glencoe (Ill.), Free Press, pp. 76-117.

- (1968-1978), Alexius Meinong Gesamtausgabe, hrsg. von R. Haller und R. Kindinger gemeinsam mit R.M. Chisholm, Akademische Druck- und Verlagsanstalt, Graz [abbreviated as GA]. 
- (1972), On Emotional Presentation, translated, with an introduction by M.L. Schubert Kalsi, with a foreword by J.N. Findlay, Evanston (IIl.), Northwestern University Press.

- (1974), 'Meinong's Ontology', in Grossmann 1974: pp. 224-229.

- (1978), 'On Objects of Higher Order and their Relationship to Internal Perception', in A. Meinong, On Objects of Higher Order and Husserl's Phenomenology, ed. by M.-L. Schubert Kalsi, The Hague/Boston/London, Nijhoff, pp. 137-200.

- (1983), On Assumptions, edited and translated, with an introduction by J. Heanue, Berkeley/Los Angeles/London, University of California Press.

Morscher, E., (1973), 'Meinongs Bedeutungslehre', Revue Internationale de Philosophie, 27, pp. 178-206.

Raspa, V., (2001), 'Zeichen, 'schattenhafte' Ausdrücke und fiktionale Gegenstände. Meinongsche Überlegungen zu einer Semiotik des Fiktiven', Zeitschrift für Semiotik, 23, pp. 57-77.

- (2005a), 'Phantasie, Phantasieerlebnisse und Vorstellungsproduktion bei Meinong', Meinong Studies / Meinong Studien, 1, pp. 95-128.

- (2005b), 'Forme del più e del meno in Meinong', in Barbero \& Raspa (eds.) 2005, pp. 185-219.

- (2006), 'La teoria dell'oggetto', in Storia dell'ontologia, M. Ferraris (ed.), Milano, Bompiani (forthcoming).

Russell, B., (1904/1973), 'Meinong's Theory of Complexes and Assumptions', Mind, n.s. XIII, pp. 204-219, 336-354, 509-524; repr. in Essays in Analysis, ed. by D. Lackey, London, Allen and Unwin, 1973, pp. 21-76.

Schuhmann, K., (2001), 'Meinongian Aesthetics', in Albertazzi, Jacquette \& Poli (eds.) 2001, pp. 517-540.

Simons, P.M. \& E. Morscher, (2001), 'Meinong's Theory of Meaning', in Albertazzi, Jacquette \& Poli (eds.) 2001, pp. 427-456.

Smith, B., (1996), 'Pleasure and its Modifications: Stephan Witasek and the Aesthetics of the Grazer Schule', Axiomathes, VII, 1-2, pp. 203-232.

Twardowski, K., (1894), Zur Lehre vom Inhalt und Gegenstand der Vorstellungen, Wien, Hölder; repr. mit einer Einleitung von R. Haller, München/Wien, Philosophia, 1982 [English translation: Twardowski 1977].

- (1977), On the Content and Object of Presentations, translated and with an introduction by R. Grossmann, The Hague, Nijhoff.

Witasek, S., (1904), Grundzüge der allgemeinen Ästhetik, Leipzig, Barth.

- (1915), 'Über ästhetische Objektivität', Zeitschrift für Philosophie und philosophische Kritik, 157, pp. 87-94, 179-199. 